\title{
Let's follow the actors! Does Actor-Network Theory have anything to contribute to science journalism?
}

\author{
Carlos Fioravanti, Lea Velho
}

\begin{abstract}
Science journalism usually focuses on achievements presented in scientific papers previously published in specialized journals. In this paper we argue that the Actor-Network Theory (ANT) can help to widen this approach and reduce the dependency on scientific papers, by valuing not only scientists, but also other actors, theirs motivations, interests and conflicts. ANT could also help to reduce the distance between scientists and the audience by exposing uncertainties about the production of science.
\end{abstract}

\section{Background}

Science journalism expresses a profound separation between those who have the relevant knowledge, voice, and power - that is scientists - and those who have neither knowledge, voice nor power - readers, also known as lay audience. Journalists, who expect to build the bridge between those groups by means of communication, base their stories primarily on scientific papers published in specialized journals. ${ }^{1,2}$

This approach seems to have worked. On the one hand, more and more scientists have been motivated to report their achievements to journalists, hoping for long, balanced, lively stories based on academic papers. Leading science journals such as Nature, Science and PNAS and websites such as Scidev.net and Eurekalert have created highly efficient press release services which facilitate the writing of accredited reporters around the world, many of whom lack efficient local news services. On the other hand, readership of science stories have increased, revealing a growing interest of the general public about the impact of scientific knowledge on everyday life, particularly on health-related issues. ${ }^{3}$

At the same time, there are challenges to be faced by scientific communication to the general public, such as the decline in newspaper sales, cuts to staffing levels and the fast-growing science blogs. Science coverage in traditional media has been scaled back in developed countries such as the US, Canada, UK and France; ${ }^{1}$ yet it has widened over the last few years in developing countries. ${ }^{4}$ Additionally, the strategy of basing journalistic stories on scientific papers is limited. Journalists and science communicators who attended the 6th World Conference of Science Journalists (WCSJ) held in London in June 2009 agreed that they should walk away from purely scientific papers and create more independent stories. The training of journalists writing about science should also be improved, in order to motivate more in-depth science reporting., $2,3,5$

As group leaders of the Association of British Science Writers (ABSW), Hollingham and Loder recommended that scientists should also be trained to improve their ability to communicate their research for other audiences and to overcome their fears of dealing with the media. ${ }^{5}$ D'Hoop urges a change in mentality in the world of science, as European research projects rarely value the communication with the general public; when they do, the communication service acts as filter rather than a genuine facilitation interface with the public.

This paper presents the Actor-Network Theory (ANT), an approach developed to examine the construction of scientific facts, as a way to address the above mentioned challenges. ANT proponents and followers argue that science is produced by scientists, but not only by them. ANT doesn't prescribe a rigid methodology, just a few recommendations summarized below. The most famous of the ANT principles is "just follow the actors", as the ANT pioneer Bruno Latour constantly reminds us. 7,8

We argue that following ANT prescriptions would widen the focus of science stories, by referencing to other social actors, considering their motivation, interests and conflicts. ANT may reduce the dependency 
of embargoed scientific papers, which have led to standardized science news and to what Oranski called lazy reporting. ${ }^{9}$ While the strategy of basing science journalism on academic papers has provided consistency for news about science, it has also strengthened the authority of scientists and widened the gap between scientists and readers.

As a consequence, the use of ANT by science journalists may add value to their work in terms of original reporting. Science journalists no longer have the time to investigate and write many original stories, usually spending their time dealing with daily science news and important announcements. This way of working "undermines one of the key reasons for having science specialists and the added value they can bring to news outlets". ${ }^{10}$ Additionally, as more scientists are communicating directly with their public, writing about science on their blogs and in regular columns in newspapers, journalists as intermediaries of information and scientific discoveries are not as essential as in the past. ${ }^{11}$ Fountain had already suggested that an ANTlike approach should be incorporated in science education if the interdependence between science and society is to be better understood. The author argues that changes in science curricula are needed so that students may understand that scientific knowledge is an outcome of contentions and negotiation processes and not mere "facts of nature" that were just awaiting to be "discovered". 12

This paper has four parts. In the first, we present the main concepts and the recommendations of the ANT, as well as some possible uses in science journalism. The second part consists of the implications of the ANT on science writing. The third part presents an example of the use of ANT in two stories about tuberculosis. We then conclude that the use of ANT by science journalists will lead to more attractive, relevant and original stories.

\section{Actor-Network Theory}

\section{Overview}

The traditional approach to examine the production of knowledge pictures scientists and engineers as exclusive actors of scientific discoveries and technological innovation. According to this view, there is little interaction with other groups of actors and the asymmetry of power is clear. The users of knowledge are seen as passive, non-creative beings, who assimilate new ideas and products apparently without any questioning, resistance or conflicts. This view is linear and unidirectional, from scientists to users, and separates science and society: scientists remain in their laboratories, inside, oblivious to outside world, while outside there exist politicians, lawyers, journalists, academic colleagues and users of knowledge. ${ }^{13}$ This view predominates among scientists and science institutions, who usually announce results of scientific work whose continuity and success, appear unquestionable.

Another way to examine the production of science is the constructivist approach of sociology of science, which considers science as a collective process. ${ }^{14}$ The Actor-Network Theory (ANT) is one strand of such a constructivist approach. Therefore, it considers that knowledge production takes place as a result of interaction of different groups of actors, not only scientists, with different interests. Science becomes a social, collective activity, which can emerge, move forward or die as a result of negotiations, impasses and conflicts between stakeholders. In science, the "construction of a fact is such a collective process so that one person builds only dreams, claims and feelings, but not facts". ${ }^{15}$ There is no longer separation between science and society, as various social actors can influence the course of science and technology.

Two key concepts of ANT are, obviously, actor and network. "Anything that modifies a state of things making a difference is an actor," Latour defines. ${ }^{16}$ One of the most distinctive ANT features is that actors can also be non-humans - a text, a machine, an institution. In a seminal paper, John Law described how important the sailing ships were for Portuguese to reach the tropics in $16^{\text {th }}$ century. ${ }^{17}$ The concept of network "refers to flows, circulations and alliances"18 and to "the ability of each actor to make other actors doing the unexpected", not to a physical object with many points connected. ${ }^{19}$

ANT values the interaction between humans themselves or between human and non-human actors. A famous soccer player would not be famous without a uniform, a ball and a field in which he could play and be observed by TV broadcasters and a wide audience. In the same way, a warrior would hardly win a war without tanks, rifles, paperwork and uniforms. ${ }^{20}$ So, non-human actors can determine the human actor's power and limits. Both human and non-human actors are interdependent beings. As any actor, 
they have no inherent qualities and "take their form and acquire their attributes as a result of their relations with others". 21

As a consequence of the interdependence actors, at least theoretically there is no longer separation between humans and non-humans, subject and object, big and small, micro and macro, local and global, particular and universal, activity and passivity, knowledge and power, before and after, context and content, materiality and sociality. Such divisions and distinctions are seen as effects or results, not part of the state of things. ${ }^{21}$ An important consequence of diluting the boundaries is that we can freely move between extremes that were distant. Murdoch stresses that only in the midfield we can observe how the world is done without basing our conclusions on discriminatory choices that usually hinder even the most sophisticated observations. $^{22}$

\section{ANT recommendations}

ANT can be attractive to journalists - and in general for anyone who produces or reads science news and looks for deeper explanations - for valuing the interaction and allowing complete freedom of movement. ${ }^{23}$ Those who adopt this approach will not have to follow rigid rules. ANT authors only offer recommendations and suggestions. This is the case of the five recommendations which Latour, along his Reassembling the social, offers those who want to adopt ANT as a way to widen their vision of science production: follow the connections, go slow, look closely, do not jump and keep everything flat.

- Follow the connections is very close to ANT' slogan, 'to follow the actors themselves' in order to learn with them how they establish new associations. "Just follow the flow. Yes, follow the actors themselves or rather that which makes them act, namely the circulating entities". 8 Following the connections means to better explore how and why the research was done, in accordance with the key questions that any journalist has to ask: who, what, when, why, where and how.

- Go slow implies mapping the territory as carefully as a cartographer to find out how the connections were made. ${ }^{24}$ ANT followers have to trudge like an ant, through painful, constantly interrupted movements, to understand how each actor is recruiting others. ${ }^{25}$ In journalist terms, go slow means not to accept the easiest conclusions or the most evident actors. Instead, one should look for the actors behind the scenes. As a result, science achievements will emerge consistently as a collective work, instead of a sudden wish of lonely scientists.

- Look close or myopically means to develop a detailed vision, instead of trying to examine everything as generalists do. An advantage for ANT followers is that "(n)ot only they can ask gross and silly questions, but they can do so obstinately and collectively". ${ }^{26} \mathrm{New}$ actors, circumstances and details will emerge, enriching the narrative.

- Don't jump or don't change the way you move. This procedure will allow you to find the main and the secondary routes, and to map the new landscape. ${ }^{27}$ Building a landscape as complete as possible - with actors, machines, institutions, and spaces - may help the reader to better understand how a scientific achievement evolves.

- Keep everything flat means to eliminate the distinctions between what earlier appeared to be separate, distant or opposite. It means "replace some mysterious structure by fully visible and empirically traceable sites". There is no longer local or global, only sites more or less connected with other sites. ${ }^{27}$ This is the most abstract and difficult recommendation to practice, because it implies transforming the apparently most powerful actors, as well as the less powerful, into points and tracing their connections and interactions. The extension and durability of the connections is what will determine the actual power and relevance of each actor.

Adele Clarke and Theresa Montini, while examining the controversy surrounding the antiabortive drug RU486, offer a broader view of the ANT, called arena analysis: "Arena analysis vividly demonstrates that there are not 'two sides' but, rather, $N$ sides or multiple perspectives on any technology. Simplification into two sides is not necessarily benign, and delimiting contestation to two sides may in itself be a hegemonic strategy". Instead of following the most powerful actor, they recommend seeing "the constructed world metaphorically over the shoulders of all the actors" and observing also the silent, collective actors, meaning those implied by the decisions, even if they didn't participate in the action. "By attempting empirically to view the world in the actors' own terms, multiple visions and means of achieving them are highlighted". ${ }^{28}$ 
Michel Callon, one of the leading ANT authors, recommends the observer to examine carefully how the actors act without overvaluing any point of view or censuring any interpretation. This methodological principle is called agnosticism of observer: the observer should be impartial to examine the scientific and technological arguments used by protagonists of a controversy. The observer should not determine the identity of the actors involved in a plot if this identity is still being negotiated - so, we shouldn't present a scientist or an achievement as relevant while he, she or it is still being built. Callon also suggests the principle of symmetry: the observer should be located at the midpoint, monitoring the expression of nonhuman and human actors at the same time. This final advice highlights the importance of being skeptical about the progress of science instead of naively adhering to the enthusiasm of a scientist who is presenting his or her fabulous achievement or has just published a paper in a leading scientific journal. What is important for them is not necessary important for the readers. ${ }^{29}$

\section{Implications}

\section{Science as collective work}

ANT values the diversity of groups of actors involved in any scientific fact. Science is a collective, not a solitary work, unlike the traditional view of science by journalists. Science reporting is centered on scientists, sometimes presented as a tacit kind of hero. Using ANT, scientists become one of the nodes of science production. News about science could bring together many actors, including non-human actors.

So, an impatient journalist could ask, what shall we do, exactly? Let's also present other actors and their expressions. The narrator of science could examine the most obvious actors, but also look for their silent colleagues, partners, collaborators, opponents, as well as the equipment, machines and institutions to whom they are connected. The connections - meaning the network - are essential to explain the history and the perspective of any achievement. Most importantly, any point in the network is a good place to start the description of the case and produce the news.

Whoever tries this broader approach should be prepared to face resistance. The first reason is that scientists are pleased with the current approach to science reporting. As a rule, they welcome the chance to communicate, but regard journalists as their spokepersons, expecting journalists to embrace the perspective of the researchers themselves. ${ }^{6,30,31}$ Claessens claims that "the system does not encourage criticism of studies published by researchers: how can a journalist, even a 'science' journalist, begin to call into question the operating mode and postulates validated by the leading scientific authorities?",31 Communication is welcome, but disagreements are not. Scientists are prepared to answer questions directly linked to their immediate paper, but are puzzled by questions such as - Why do you believe your research is relevant? What is your plan to continue this study? Do you want to save the world?

Experienced analysts of science have long found out that scientists don't appreciate being contested by non-scientists, and they also dislike sharing the headlines with equally highly qualified colleagues. Journalists are sometimes perceived by scientists as a threat because they may distort the content of scientific papers, lack precision and rigour and create public controversy, "a risk that few seem prepared to take". ${ }^{6}$ Based on a mail survey of 1354 researchers in five countries (United States, Japan, Germany, United Kingdom, and France), Peters et al. noted that many scientists are worried about the lack of control of the journalistic work, the "risk of incorrect quotation" in stories and the "unpredictability of journalists". ${ }^{32}$

\section{Science as interaction}

Power is socially built, according to ANT. As any actor acquires his or her qualities while interacting with other actors, each actor should be examined connected with other actors - a man with a machine he uses, with the microbe he studies, with the institution which funds him; this man wouldn't be relevant without such a machine, microbe or institution. Each of these actors is equally important to understand what happened. An actor is only an actor if he is part of a network.

Our impatient journalist would again ask what to do, exactly? Simple: let's pay more attention to the conflicts, the challenges, the original (or not so original) solutions which a scientist faces, as well as his or her alliances with machines, institutions or microbes - and present them when relevant to explain a 
scientific fact. Now we can describe how actors become actors, by interacting with other actors. Which institutions, machines or circumstances determine the power of the main actors? What are their limits?

An important lesson of ANT is that science advances are not due exclusively to desires of scientists, policymakers, customers or readers, but as a consequence of negotiations and successful alliances between them. The best groups with the best ideas will not necessarily triumph. The winners will be the most connected ones, as the effective power of any actor depends on his or her connections - any actor is essentially an actor-network. So, our impatient journalist could examine the connections which any scientist has already forged or wants to forge. Where this scientist goes, who he or she talks to? Independently of his or her announced plans, how far does he or she go beyond laboratory walls? Is he or she a good negotiator?

\section{No longer general, easy explanations}

Using ANT, tangible elements replace abstract ones. As Latour would say, explanations based on social don't explain anything. Explanations based on "global forces of society", "papers given by the social expectations" or "bad faith" also loose meaning. There are no longer hidden social forces. ${ }^{33}$ Context is another term to be abandoned.

Following the actors and transforming everything into visible sites may help us to walk away from mysterious forces and entities, such as government and generic scientists, and to identify the specific governmental institutions, as their officers, and named scientists who work for or against any promising scientific idea. Identifying the allies and the opponents clearly provide more consistent explanations than those easily given by context or social expectations.

\section{Science as an uncertainty}

As science news producers and readers, we shouldn't want to see what doesn't exist.

Scientists can present their achievements enthusiastically, but nothing guarantees that they will indeed reach theirs goals. Our hurried journalist could use more conditionals, such as if, and consider the possibility of the achievement not going as fast as expected.

One of the authors (CF), as part of his $\mathrm{PhD}$ thesis, examined what happened to 26 promising molecules which were announced as future medicines in scientific papers and in general newspapers and magazines in Brazil since 1996. None of the molecules reached the announced goals. An analysis of such cases using ANT shows that scientists were not able to build alliances with academic institutions or pharmaceutical companies needed to develop their molecules.

\section{No more discovery or magic: new vocabulary required}

Science, now seen as a social, collective construction, does not emerge from privileged minds working isolate. A social, long term, exhausting process is necessary. All scientists know there is no magic in the production of science, but many times they choose to simplify the long, sinuous research course, avoiding details that hurried journalists prefer not to know.

ANT implies a few changes in the verbs most used in science news. Instead of saying that a scientist discovered anything, as an astonishing fact, we could say that the scientist has evidenced or has verified something. Now an experiment doesn't show or reveal anything anymore, just suggests or indicates, as other equipment or approach could lead to different results. This is a subtle change, which would help to build friendlier or less patronizing texts. It is also a real problem, as more powerful verbs are more efficient for journalist to convince their editors about the importance of the science news than moderate verbs.

In newspapers and magazines, the headlines contain the most important news stories, while science news, normally discrete, is set aside to inside pages, except when it can change the world and can be easily understood. The more the news is in line with the sensationalist mainstream, the more superficial is the coverage. ${ }^{34}$

The search for an appropriate vocabulary, even if it is not adequate or advisable to win the competition with other news, may add value to the work of science writers. Franzoni claims that: "More than in any other branch of journalism, the science writer must investigate to the maximum in the shortest possible 
time. In the process, the journalist themselves becomes a kind of 'mini-researcher', thereby moving even closer to their principal interlocutor, the scientist". ${ }^{34}$

\section{Journalists as mediators, not only intermediaries}

Many academic studies based on ANT adopt two concepts - intermediary and mediator - which can be relevant for journalists. Very briefly, an intermediary is like a postman, just bearing information without transforming it; what the intermediary receives is what he or she will deliver. Mediators are creative and unpredictable, as they "transform, translate, distort, and modify the meaning or the elements they are supposed to carry"; what a mediator hands in can be very different from what he or she received. ${ }^{35}$

While examining science as a collective work and giving voice to other actors beyond the most powerful, the science journalist tends to transform his or her role as an intermediary into a mediator. Doing so, the journalist may elucidate the relevance of scientific news on his or her own, expose established connections and stimulate new ones, and create his or her own paths and conclusions. Traditional scientists, who prefer to see journalists just as intermediaries, just writing about science and scientists accurately, cannot enjoy this new journalist's role, but the reader will likely enjoy it. Journalists, as mediator, should maintain a dialogue between the world of science on one hand and the world of society and the media on the other. ${ }^{6}$

Being a mediator instead of an intermediary implies thinking independently and considering many points of view, not just the scientist's view, so widening the public understanding of science and rendering science exciting, as scientists rarely do. ${ }^{2}$ Franzoni warns that science journalists "must adopt a more neutral and critical stance, remain aware of their own choices and perspectives, and inform the public of the implications of the discovery, both positive and negative"; in summary, they "must remain independent as much as possible". ${ }^{34}$ The approach proposed by her is broader than that put forward by Meyers, who highlights the importance of knowledge brokers, which can be a special kind of intermediaries. ${ }^{36}$

The definition of the journalistic role helps to clarify the difference between science communication and science journalism. Hollingham and Loder claim that a great difference between science journalism and science communication is that journalism has the potential to include wider views; scientists may not always share the journalistic views. Hollingham and Loder argue that many times initiatives from governmental agencies in science journalism often sound like propaganda and can undermine the public trust in journalists. ${ }^{5}$ The rising of bloggers, many of them led by young scientists, has created a new, democratic way to spread science news which has reduced the role of journalists as essential intermediaries. ${ }^{1,37}$ Being a mediator and going beyond the ordinary news can help to value journalists as specialized professionals on dealing with in-depth information.

\section{Bringing ANT and Science Journalism together}

Two stories about tuberculosis exemplify how ANT can be used to enrich the journalistic work. The first $^{38}$ presented a non-human actor - a new strain of more dangerous bacteria which had emerged in Rio de Janeiro - as a starting point to discuss the network of actors involved with the disease. By following the bacteria, the lack of connections between human actors emerged clearly.

The results of the scientific work, such as that announcing a more powerful strain of Mycobacterium tuberculosis, rarely translated into new ways to diagnose or treat tuberculosis. Finding new allies was a challenging task even between physicians. One of them remembered an old joke among experts on TB in Brazilian hospitals: when two of them meet, they discuss at least three proposals to save the world from TB. Scientists, physicians and policymakers recognized that they should work together - when they did so, TB incidence decreased.

In the story, Manuel Bandeira, a Brazilian poet who died from tuberculosis, acted as a mediator, transforming a distant, epidemiologic problem into an individual tragedy. He synthesized his profound sense of loss due to tuberculosis in the poem "Pneumothorax":

Fever, hemoptysis, dyspnea and nocturnal perspiration.

An entire life that might have been and was not.

Cough, cough, cough. 
The story also showed that the network of actors was wider and stronger ten years earlier.

Then, anyone could participate buying stickers which helped to support public campaigns against TB. Also, TB screening tests were required prior to school or job entrance.

The second story ${ }^{39}$ described the obstacles to develop and to release new drugs to treat TB, which were announced in the past few years. Officers, scientists and physicians from rich and poor countries, interviewed at an international medical meeting on TB in December 2009 in Cancun, Mexico, recognized that such difficulties result of the increasing TB bacteria resistance to antibiotics, lack of local infrastructure for diagnoses and treatment, increasing poverty in the most affected countries, and fragile collaboration between governmental, scientific and private organizations. New drugs, when they emerge, will be ineffective if the people who most need them can not reach a medical center. So, good roads to hospitals are as important as medicines. In ANT terms, humans and non-human would have to be connected adequately to solve the problem.

The article highlighted new actors who were helping to control the spread of the disease. NGOs such as TB Alliance and Areas Vaccines were working with communities on promising, new molecules, while international medical societies taught Chinese students to detect TB symptoms in their families, and former patients helped to treat new patients in small communities in Tanzania.

\section{Conclusions}

ANT offers an array of tools which are useful to write more diversified, lively science reporting. It may contribute to reducing the dependence on embargoed journals, expanding the vision of science beyond the scientists and their achievements, valuing other sources of science news, and publishing exclusive stories. Much more can be exposed, in more exciting ways.

\section{Notes and references}

1 G. Brumfiel (2009), Science journalism: Supplanting the old media?, Nature 19(458): 274-277.

2 V. de Semir (2010), Science Communication \& Science Journalism. Media for Science Forum, Madrid, 12-13 May 2010. Available at:

http://www.mediaforscience.com/Resources/documentos/booklet_en.pdf.

3 F. Fox et al. (2010), Science and the Media: Securing the Future. Science and the Media Expert Group, Available at: http://interactive.bis.gov.uk/scienceandsociety/site/media//.

4 A. Irwin (2009), Science journalism 'flourishing' in developing world, Scidev.net, Available at: http://www.scidev.net/en/news/science-journalism-flourishing-in-developing-world.html.

5 R. Hollingham and N. Loder (2009), Association of British Science Writers (ABSW) submission to the BIS Science and Media Expert group, Submitted 9.11.09. Available at: http://interactive.bis.gov.uk/scienceandsociety/site/media/files/2010/03/Annex-3b-submission-by-ABSW.pdf.

6 D. D’Hoop (2008), Barcelona: science comes to town, Research EU, 56 June 2008, p.10-11.

7 B. Latour (2005), Reassembling the social: An introduction to Actor-Network Theory, Oxford, UK: Oxford University Press, 2005, p. 12.

8 B. Latour (2005), op. cit., p. 237.

9 I. Oransky (2006), Lawrence K. Altmann, The Lancet 368, p. 1231.

10 R. Hollingham and N. Loder, op. cit., p. 2.

11 V. de Semir, op. cit., p.5

12 RM. Fountain (1999), Socioscientific issues via actor network theory, Journal of Curriculum Studies 31(3): 339-358.

13 B. Latour (2000), Ciência em ação: como seguir cientistas e engenheiros sociedade afora, São Paulo Editora Unesp (2000), p. 258-262.

14 K. Knorr-Cetina and M. Mulkay (1985), Science Observed. Perspectives on the Social Study of Science. London, Sage.

15 B. Latour (2000), op. cit., p. 70-71.

16 B. Latour (2005), op. cit., p. 71. 
17 J. Law (1986), On the methods of long-distance control: vessels, navigators and the Portuguese route to India, in J. Law (ed.). Power Action and Belief: A New Sociology of Knowledge? London, UK Routledge and Henley, p. 234-63.

18 L.L. Freire (2006), Seguindo Bruno Latour: Notas para uma antropologia simétrica, Comum. 11(26): 46-65.

19 B. Latour (2005), op. cit., p. 128-131.

20 B. Latour (2005), op. cit., p. 75.

21 J. Law (1999), After ANT: Complexity, naming and topology, in J. Law and J. Hassard (eds.), Actor Network Theory and after. Oxford, UK: Blackwell Publishers, p. 1-14.

22 J. Murdoch (1997), Towards a geography of heterogeneous associations. Progress in Human Geography 21(3): 321-37.

23 B. Latour (2005), op. cit., p. 52.

24 B. Latour (2005), op. cit., p. 190

25 B. Latour (2005), op. cit., p. 25.

26 B. Latour (2005), op. cit., p. 175.

27 B. Latour (2005), op. cit., p. 179.

28 A. Clarke and T. Montini (1993), The many faces of RU486: Tales of situated knowledges and technological contestations, Science Technology Human Values 18(1): 42-78.

29 M. Callon (1986), Some elements of a sociology of translation: Domestication of the scallops and the fishermen of St. Brieuc Bay, in J. Law (org.). Power, action and belief: a new sociology of knowledge? London, Routledge, p. 196-223.

30 V. de Semir, op. cit., p. 15.

31 M. Claessens (2008), Does science journalism exist? Research EU. 56 June 2008, p.2.

32 H.P. Peters et al. (2008), Interactions with the Mass Media, Science 321: p. 204-205. Available at: http://juwel.fz-juelich.de:8080/dspace/bitstream/2128/3129/1/reprint3215886204.pdf.

33 B. Latour (2005), op. cit., p. 47.

34 C. Franzoni (2008), Portrait of a singular discipline. Research EU. 56 June 2008, p.14.

35 B. Latour (2005), op. cit., p. 39.

36 M. Meyer (2010), The rise of the knowledge broker. Science Communication 32(1): 118-127.

37 V. de Semir, op. cit., p. 5.

38 C. Fioravanti (2008), Mortal drama, Pesquisa Fapesp 146. Available at: http://revistapesquisa.fapesp.br/?art=2180\&bd=1\&pg=1\&lg=en.

39 C. Fioravanti (2010), Difficult progress, Pesquisa Fapesp 167. Available at: http://www.revistapesquisa.fapesp.br/?art=2623\&bd=1\&pg=1\&lg=en.

\section{Authors}

Carlos Fioravanti is a science journalist who has written about science, environment and technology since 1987. In 2007 he was awarded a Fellowship at Reuters Institute for the Study of Journalism at Oxford University, Oxford, UK, and in 2010 he concluded his PhD research at the Department of Science and Technology of the State University of Campinas (Unicamp), Brazil. E-mail: chfioravanti@gmail.com.

Lea Velho is Full Professor in Science and Technology Policy at the Department of Science and Technology Policy of the State University of Campinas (Unicamp), Brazil. She has a PhD degree from Sussex University, UK, and has been visiting scholar to Edinburgh University, UK; Ohio State University, Cornell University and Indiana University, USA. She has also worked as senior researcher at the United Nations University Institute for New Technologies (UNU-INTECH) in Maastricht, the Netherlands. E-mail: velho@ige.unicamp.br.

How TO CITE: $\quad$ C. Fioravanti and L. Velho, Let's follow the actors! Does Actor-Network Theory have anything to contribute to science journalism?, Jcom 09(04) (2010) A02. 